Coastal Morphodynamics at Skallingen, SW Denmark High Energy Conditions

Aagaard, Troels; Nielsen, Jørgen; Davidson-Arnott, Robin; Greenwood, Brian; Nielsen, Niels

Published in:

Geografisk Tidsskrift

Publication date:

1998

Document version

Publisher's PDF, also known as Version of record

Citation for published version (APA):

Aagaard, T., Nielsen, J., Davidson-Arnott, R., Greenwood, B., \& Nielsen, N. (1998). Coastal Morphodynamics at Skallingen, SW Denmark: High Energy Conditions. Geografisk Tidsskrift, 98, 20-30. 


\title{
Coastal Morphodynamics at Skallingen, SW Denmark: High Energy Conditions
}

\author{
Troels Aagaard, Jørgen Nielsen, Robin Davidson-Arnott, Brian Greenwood \& Niels Nielsen
}

\begin{abstract}
The present paper discusses some preliminary results from a field experiment on sediment transport and morphological change on a beach subjected to storm surge activity. The data were collected at the barrier spit of Skallingen during October/November 1996. This period was characterized by a succession of storms which resulted in high water and wave energy levels, culminating in a storm surge per se. The beach and the dune ramp eroded; however, contrary to expectations, a subtidal bar migrated onshore and the intertidal swash bar appeared to display a cyclic behaviour dependent upon strong linkages between morphology and hydrodynamics. Morphological changes in the intertidal zone were primarily accomplished by mean currents with oscillatory motions playing a subordinate role. Longshore sediment transport measured during conditions with moderately strong winds blowing alongshore, was dominated by wave-induced currents with aeolian transport being a secondary contribution. Preliminary estimates suggest that some $30-35 \%$ of the sediment eroded from the beach and dunes is re-
\end{abstract}

tained on the barrier through onshore aeolian transport and overwash activity.

\section{Keywords}

Sediment transport, storm surge, sediment budget, swash burs, aeolian processes.

Troels Aagaard, Jorgen Nielsen \& Niels Nielsen: Institute of Geography, University of Copenhagen, Øster Voldgade 10,DK-1350 Copenhagen K., Denmark.

Robin Davidson-Arnott: Department of Geography, University of Guelph, Guelph, Ontario NIG 2WI, Canada.

Brian Greenwood: Scarbrough College Coastal Research Group, University of Toronto at Scarborough, Scarborough, Ontario MIC IA4, Canada.

Geografisk Tidsskrift, Danish Journal of Geography 1998: 20-30.
Within recent decades there has been an increasing interest concerning the behaviour of barrier beaches. This has been due in part to the erosion of beaches worldwide caused by depletion of offshore sediment sources, sea level rise and human interference (Bird, 1993). This erosion is expected to continue and increase due to the fact that global sea level rise is expected to accelerate within the near future. Furthermore, barriers which comprise some $15 \%$ of the world's shoreline are some of the most sensitive coastal elements while at the same time carrying large amounts of infrastructure, particularly in the US, where urban development has increased by more than $50 \%$ since 1945 (Viles and Spencer, 1995), but also along the Danish North Sea coast where harbours (e.g. Hvide Sande, Torsminde, Thyborøn) are located on barriers, or protected by them (e.g. Esbjerg). Barriers also protect low-lying agricultural areas and, finally, they are important locations for cottages and the tourist industry.

Erosion of barriers occurs during storms when dunes are scarped or breached, and overwash may occur at sites where dunes are destroyed or absent, eventually leading to 'roll-over' and landward transgression of the barrier (Swift, 1975; Carter, 1988; Aagaard et al., 1995a). Documentation of the mechanisms leading to beach/barrier erosion and transgression have almost exclusively been indirect in the form of surveying before and after storms (e.g. Ritchie and Penland, 1988; Dingler and Reiss, 1990; Birkemeier et al., 1991) or analysis of aerial photographs (e.g. Kahn and Roberts, 1982).

Process-based studies of beach and surf zone morphodynamics during storms have been rare, not only on barriers but in general. The main reason is that until recently, 
instruments capable of measuring waves, currents and sediment transport were lacking. Furthermore, installation and operation of a sufficiently large number of such instruments require sizeable resources in terms of manpower and funding. Consequently, quantitative measurements of sediment transport magnitudes (and directions) which are necessary to obtain detailed sediment budget estimates during erosional and accretionary events, as well as the hydrodynamic processes involved in this exchange of sediment, have rarely been obtained.

In this paper, we report on the morphological consequences of a series of four storms occurring on the barrier spit of Skallingen, SW Denmark during the fall of 1996. These storms caused beach erosion and minor dune scarping as well as overwash on pre-existing fans and aeolian transfer of sand to the back of the dunes. This paper presents an overview of the processes occurring at this barrier during high-energy conditions with a focus on cross-shore profile development and the volumetric changes involved, as well as longshore sediment transport rates. Furthermore, the components making up the sediment budget of the barrier are subjected to a preliminary evaluation.

\section{Field site and research methods}

A basic description of the field site and instruments deployed is contained in Aagaard et al. (1995b). The present experiment occurred at Survey Line 6420, established by the Coastal Authority (Figure 1). The experiment was conducted over the period October 21-November 19, 1996 (Julian Days 295-324). Measurements of hydrodynamics and suspended sediment transport were made at five instrument stations deployed in a cross-shore transect across the beach and inner nearshore (Figure 2). These stations were each equipped with a Marsh-McBirney OEM512 electromagnetic current meter and three optical backscatter suspended solids sensors (OBS-1P) deployed at $0.05,0.10$ and $0.20 \mathrm{~m}$ above the bed. Instruments were adjusted vertically whenever possible to compensate for bed elevation changes. The backscatter sensors were calibrated after the experiment at the Sediment Recirculating Facility at the University of Toronto using sand from the deployment locations while the current meters were calibrated using the manufacturer's specifications. Sensor offsets were, however, checked prior to and after the experiment. Stations S1 and S4 were also equipped with Varian pressure

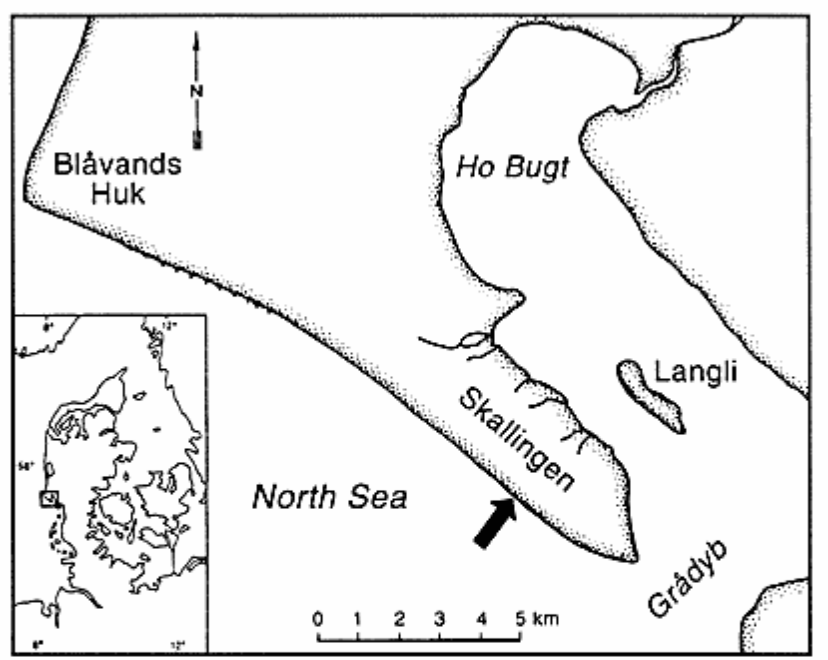

Figure I: Map of Skallingen, The experimental site is indicated with an arrow.

sensors (Hazen et al., 1989) for wave and set-up measurements. A further instrument station (S6) was deployed approximately $150 \mathrm{~m}$ south of the main transect in an incipient rip channel which, however, infilled soon after installation.

The sensors were all cable-linked to a data acquisition system housed in a trailer behind the dunes and sampled at $4 \mathrm{~Hz}$ for periods of 34 minutes every $1-1 \frac{1}{2}$ hours during storm events. Net suspended sediment flux at a point was computed from the cross-product of current velocity (u) and suspended sediment concentration (c):

$$
\left\langle\mathrm{q}_{\mathrm{s}}\right\rangle_{\mathrm{n}}=1 / \mathrm{N} \Sigma \mathrm{uc}
$$

where $\mathrm{N}$ is the number of data points in each record. Longshore sediment transport at a given station was computed by integrating sediment flux over the vertical $0.025-0.275 \mathrm{~m}$. Total longshore sediment transport in the inner surf zone was found by horizontally integrating transport at the five instrument stations. Transport further offshore particularly along the second bar is thus not considered.

Offshore waves and tides were recorded using a Pacer 10688 WTG deployed in a water depth of $-4.7 \mathrm{~m} \mathrm{DNN}$, approximately $650 \mathrm{~m}$ from the shoreline. This sensor sampled wave heights for a period of 17 minutes at a rate of $2 \mathrm{~Hz}$ every 2 hours; the mean water level (i.e. tidal stage) was recorded each 7.5 minutes. 


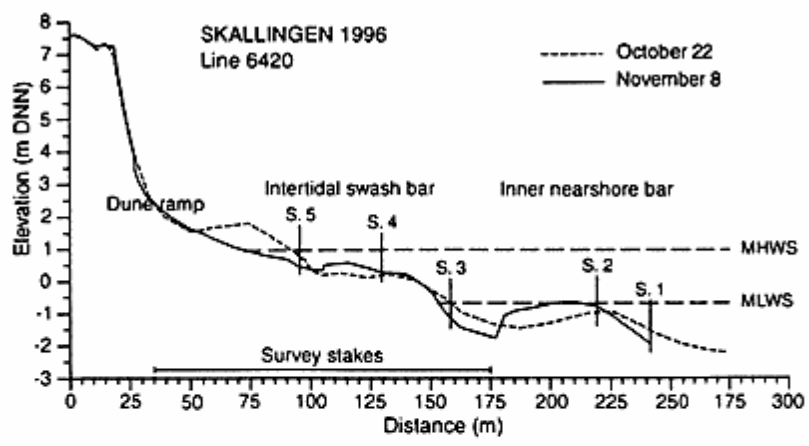

Figure 2: Cross-shore profile at the experimental site surveyed on Oct. 22 and Nov. 8. The locations of instrument stations SI-S5 are indicated.

Cross-shore profile changes were documented using a cross-shore array of $29,1 / 2$-inch diameter survey stakes spaced $5 \mathrm{~m}$ apart from $\mathrm{x}=35-175 \mathrm{~m}$ (Figure 2). The top of the stakes was surveyed relative to a fixed datum and bed elevation changes were recorded at each low tide throughout the experiment. The tide at Skallingen is semi-diurnal with spring and neap tidal ranges of $1.7 \mathrm{~m}$ and $1.3 \mathrm{~m}$, respectively. On occasion, conventional surveying techniques were applied to extend the profile further offshore.

Aeolian transport rates in the intertidal zone and along the backshore/dune ramp were measured using vertical wedge-shaped traps based on the design of Nickling and McKenna Neuman (1997). These traps have a height of $0.62 \mathrm{~m}$ with an opening of $0.15 \mathrm{~m}$ while the back of the trap is covered with $0.06 \mathrm{~mm}$ stainless steel wire mesh (Davidson-Arnott et al., 1997). Sediment is collected in a plastic bag fitted over a pipe installed in the bottom of the trap. Four of these traps were deployed in a cross-shore transect across the backshore and spaced 5-10 m apart. Sampling occurred over 10-15 minute periods on two days with near-optimal aeolian transport conditions on the beach. Local wind speed was measured using Gill-type three-cup anemometers which were either hand-held at 2 $\mathrm{m}$ above the bed, or fixed at stakes and hard-wired to the data acquisition system in the trailer.

Measurements of aeolian accretion in the dunes were carried out using a bedframe device (Davidson-Arnott and Law, 1990, 1996); the distance from an aluminium frame to the bed was determined at 12 fixed positions within a $1 \times 1 \mathrm{~m}$ grid. Twenty-six grids were established along three transects spaced $25 \mathrm{~m}$ apart and crossing the foredune at the research site. Within each transect, grids were spaced 5-10 $\mathrm{m}$ apart from the aeolian dune ramp to a distance of

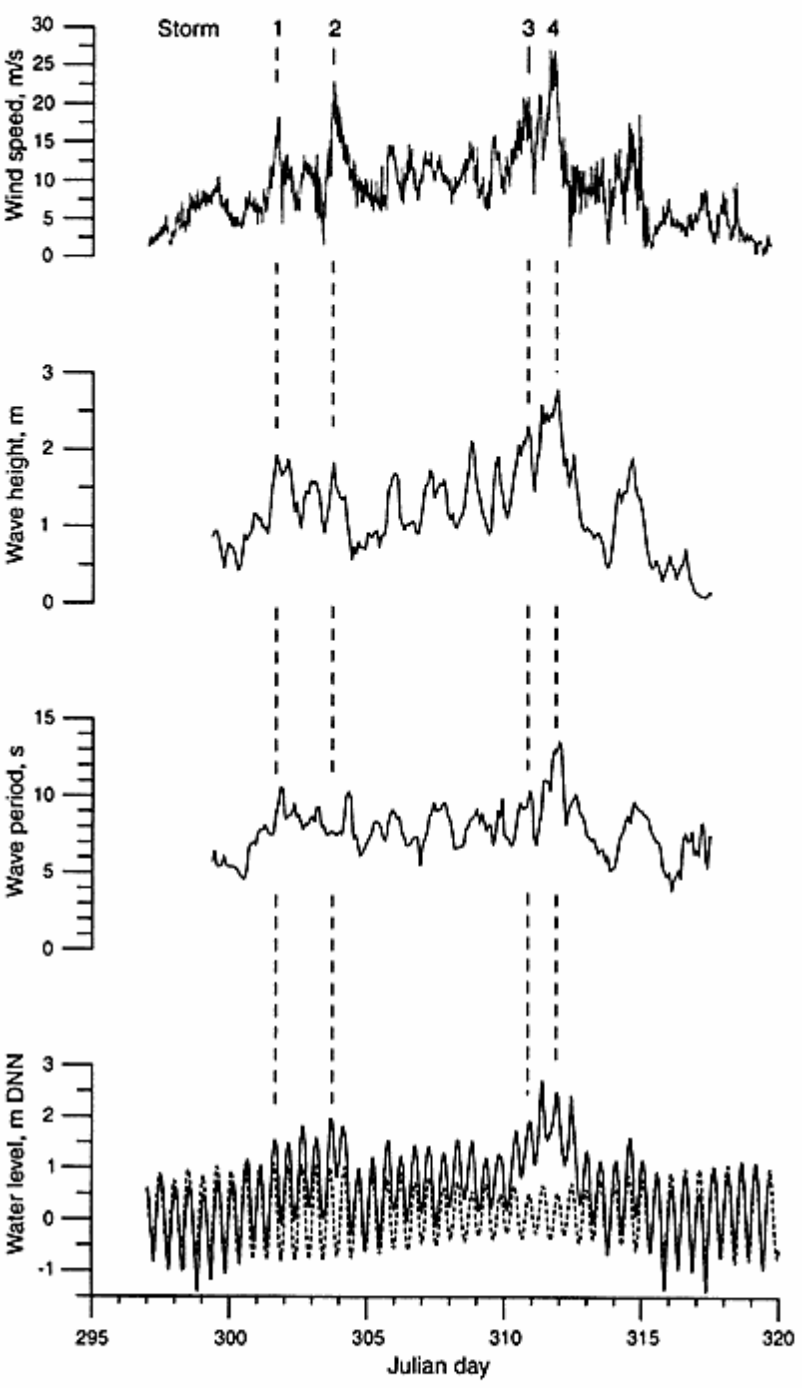

Figure 3: Environmental conditions during the experiment. From top down, the panels show: Wind speed measured at Esbjerg, significant wave heights at a water depth of $-4.7 \mathrm{~m}$ DNN, peak spectral wave periods and water level at Esbjerg Harbour. The dashed line in the lower panel is the predicted tide at Esbjerg. Storms 1.4 are discussed in the text.

approximately $20 \mathrm{~m}$ inland from the dune crest. One of the transects extended to a distance $45 \mathrm{~m}$ inland. These grids were surveyed twice during the experimental period (Nov. 3 and 8 , this period spanning two major storms); they were resurveyed in May and November 1997 to provide information on long-term dune accretion.

Finally, regional wind speed and direction as well as mean water level at Grådyb Barre were supplied by the Esbjerg Harbour Authority. 


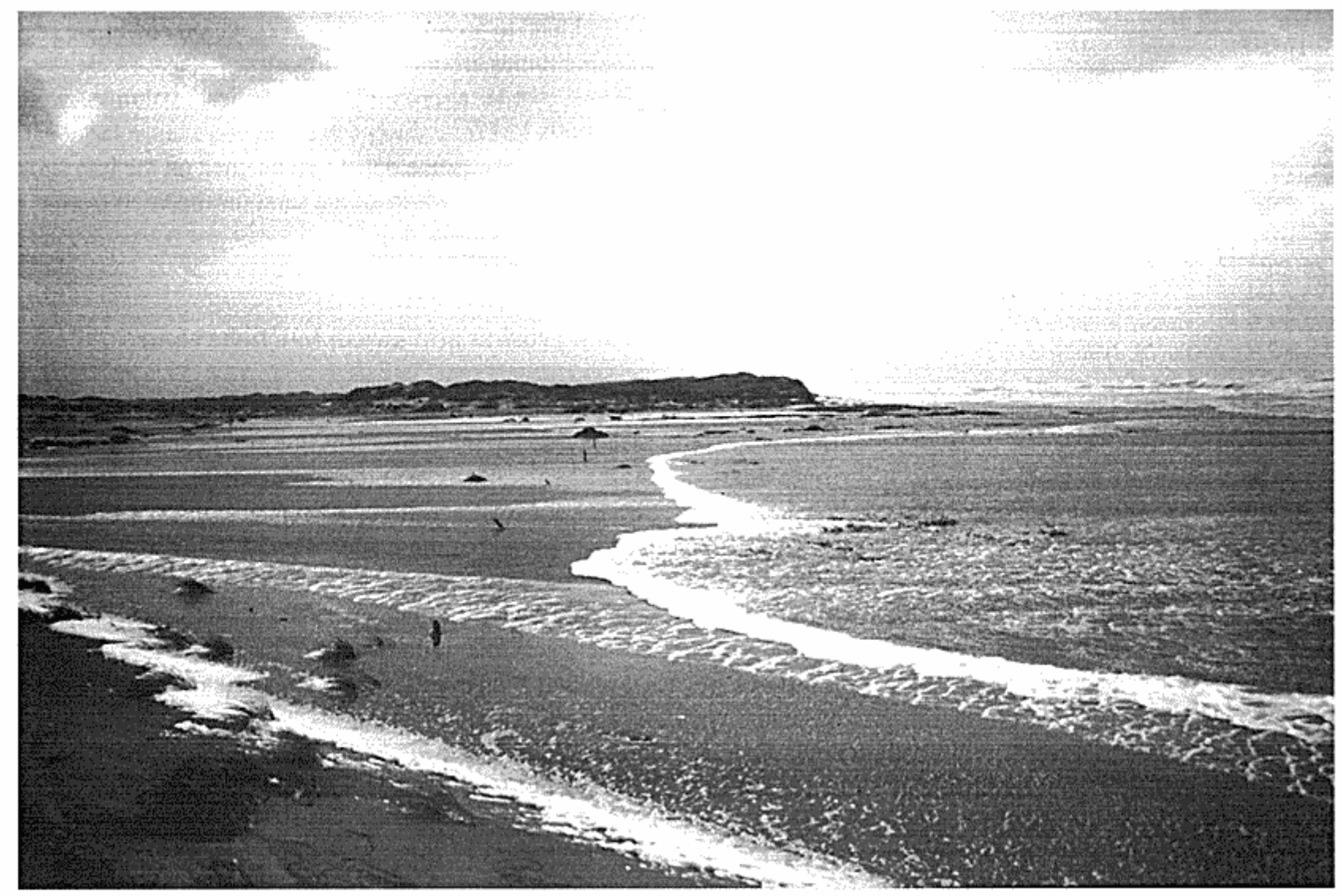

Figure 4: Overwash at Skallingen on Nov, 6. The photo was taken at half-tide (ebbing). Note the low bores traversing the fan, setting up almost unidirectional landward currents resulting in an onshore directed sediment transport once the bores have passed the highest point of the fan (refer Figure 5).

\section{Winds, waves and water levels}

The two-week period October 27-November 10 (JD301JD315) was characterized by a continuous series of approximately ten meteorological depressions passing the research site, generating strong onshore winds from the SW through NW sectors.

On one occasion, Nov.6, winds reached speeds of 27 $\mathrm{m} / \mathrm{s}$, i.e. storm force winds (Figure 3 ). These meteorological conditions resulted in persistently elevated water levels at the field site and in Esbjerg Harbour; the largest surge (on Nov. 6) led to water levels of $+2.74 \mathrm{~m} \mathrm{DNN}$ at Esbjerg and approximately $+2.20 \mathrm{~m} \mathrm{DNN}$ at the wave recorder off the field site (Figure 3). Mean spring high water at Esbjerg Harbour is $+0.96 \mathrm{~m} \mathrm{DNN}$, and predicted high water on Nov. 6 was $+0.66 \mathrm{~m}$, indicating a storm surge of $2.08 \mathrm{~m}$ at Esbjerg. Offshore significant wave heights reached or exceeded $2.0 \mathrm{~m}$ on several occasions during the experiment with a maximum of $2.8 \mathrm{~m}$ reached on Nov. 6 . The Nov. 6-storm also resulted in unusually long incident wave periods; peak spectral periods $\left(\mathrm{T}_{\mathrm{p}}\right)$ reached 13.5 seconds. Most of the other storms occurring within the research period also exceeded in intensity the storms monitored during the 1994-95 field seasons (Aagaard et al., 1995b; Aagaard et al, in press).

\section{Morphological response and volumetric changes}

The morphological response to this series of high-energy events was an erosion of the swash bar at $\mathrm{x} \sim 75 \mathrm{~m}$ with renewed swash bar formation at $\mathrm{x} \sim 135 \mathrm{~m}$ and subsequent onshore migration of this new swash bar (Figure 2). The dune ramp receded by some $3 \mathrm{~m}$ during the storm surge on 


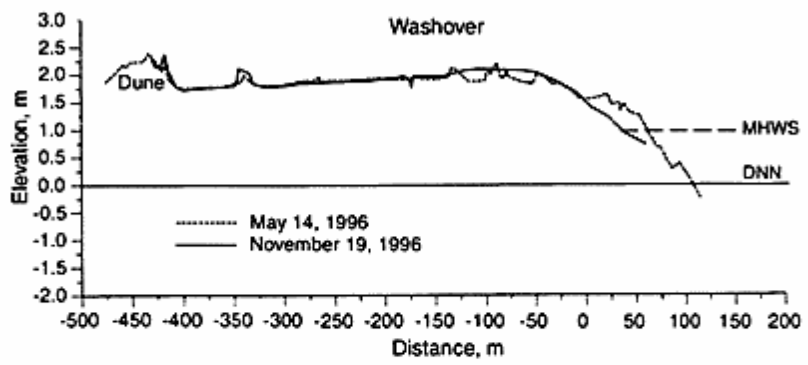

Figure 5: Cross-shore profile of the washover fan, surveyed on May 14 and November 19, 1996.

Nov. 6. Finally, the inner nearshore bar migrated some 30 $\mathrm{m}$ landward which was contrary to expectations as nearshore bars generally migrate offshore during high-energy conditions (e.g. Wright \& Short, 1984; Sallenger et al., 1985; Aagaard \& Greenwood, 1995). In total, the crosssection between $x=27-175 \mathrm{~m}$, comprising the dune ramp, the beach and the swash bar system lost approximately $26.6 \mathrm{~m}^{3}$ of sand per $\mathrm{m}$ shoreline. By including the inner nearshore bar in this estimate, the loss increases to approximately $31.7 \mathrm{~m}^{3} / \mathrm{m}$ shoreline. Because echo-surveys were only carried out once, it is not known how much of this sediment was transported further offshore to feed the outer bar and the deeper parts of the profile (if any) and how much was lost downcoast (i.e. to the south) due to transport by the longshore currents.

Some $5 \frac{1}{2}$ kilometers north of the field site, a washover fan was subjected to overwash on Nov. 6 . The beach and the incipient foredunes at $\mathrm{x} \sim \div 125-\div 50 \mathrm{~m}$ were eroded while sediment was transported landward by the almost unidirectional currents generated by low surf bores traversing the gently sloping fan (Figure 4). While this fan was not surveyed at the beginning of the experiment, an amount of $22.1 \mathrm{~m}^{3} / \mathrm{m}$ was eroded from the beach (between $x=\div 50-+85 \mathrm{~m}$; Figure 5) between mid-May and midNovember, almost corresponding to the amount eroded from the beach at the experimental site. It is probable that most, if not all, of this erosion was realized during the experimental period because no significant storms occurred between May and late October. Furthermore, an examination of the Esbjerg tidal records suggests that overwash did not occur from May until November 6, 1996. Therefore, an amount of $12.3 \mathrm{~m}^{3} / \mathrm{m}$ of sand appears to have been deposited by this overwash event between $x=\div 200$ $\div 50 \mathrm{~m}$. Significant aeolian deposition on the fan surface over the summer appears unlikely as this sand is dry and removed by relatively light winds. Aeolian sand will instead tend to accumulate in the vegetation and in the preexisting dunes around the fan margins.

Thus, while approximately identical volumes were apparently lost from the beach at the two sites, a large part of this sediment (some 55\%) was retained on the barrier at the washover fan, while all the sand disappeared from the dune site at Line 6420.

\section{Beach erosion and swash bar behaviour}

Morphological changes through time (Oct. 27-Nov.17; JD301-322) at the instrument line are shown in Figure 6. At the beginning of the experiment, a large swash bar was located at a relatively high elevation, centered at $\mathbf{x} \sim 70 \mathrm{~m}$. The temporal evolution of this swash bar was somewhat different from classic concepts of beach behaviour, which state that during storms, pre-existing swash bars or berms erode while the sediment is transported offshore (e.g. Hayes and Boothroyd, 1969; Komar, 1976). The following will focus on the effects of the four storms, numbered in Figure 3, which showed a gradual increase in energy level in terms of offshore wave heights and water levels.

During Storm 1, the swash bar and associated runnel were driven not offshore, but onshore. The sediment transport stations were unfortunately located too far seaward to document and explain this behaviour during the present experiment. However, a similar development was observed and documented during the 1995-experiment (Aagaard et al., 1998). On that occasion, the swash bar was driven onshore by mean flows which were generated by onshore mass transport in the incident waves. The onshore water discharge was channelled alongshore in the runnel and finally offshore through a small rip channel, resembling a cell circulation system on the intertidal beach. Visual observations suggested that similar processes occurred on the present occasion with onshore water discharge draining seaward through a rip channel approximately $150 \mathrm{~m}$ south of the instrument transect.

During Storm 2, the runnel behind the swash bar was finally infilled by onshore sediment transport; lateral drainage was inhibited and the swash bar eroded (Figure 7a); simultaneously the rip channel south of the transect infilled. Approximately $0.55 \mathrm{~m}$ of erosion occurred at the swash bar crest over the two tidal cycles encompassing this storm; however, visual observations indicated that the erosion and eradication of the bar were accomplished within 


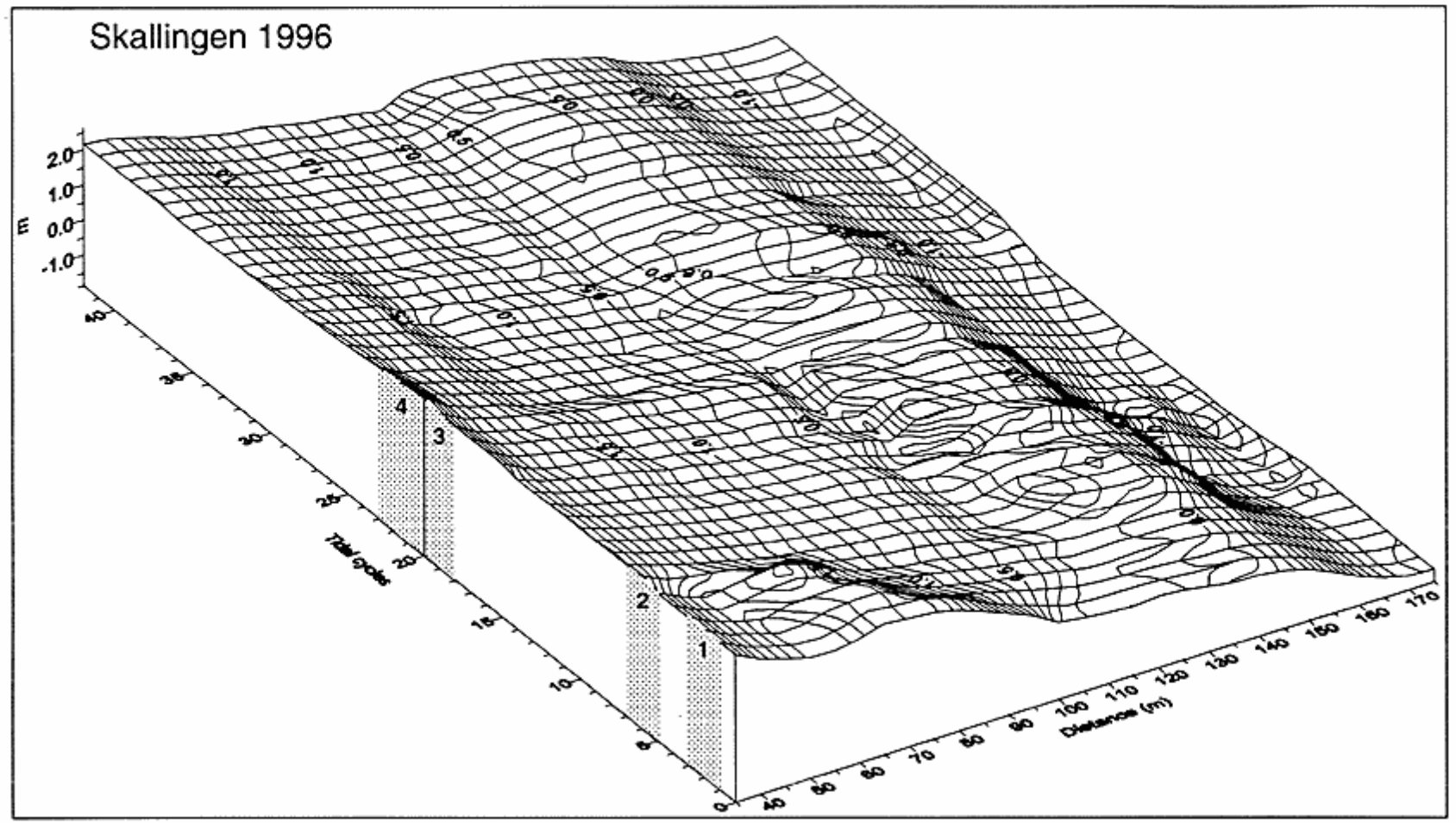

Figure 6: Time-distance diagram showing the morphological evolution of the intertidal beach and inner nearshore. The axes are respectively distance from the baseline in the dunes, elevation, and time represented by the number of low tides (tidal cycles) from the beginning of the experiment. Storm 1 occurred over tidal cycles 1-3, Storm 2 over cycles 5-7, Storm 3 over cycles $18-20$ and Storm 4 over cycles 20-23.

a time span of only two hours early in the event. At the same time, a new swash bar accreted further seaward (Figure $7 \mathrm{a}$ ), the accretion being on the order of $0.2-0.3 \mathrm{~m}$ over the course of this storm.

Suspended sediment flux vectors representing a high-tide and a low-tide situation, respectively, are shown in Figure 8 for stations S3-S5. This figure shows a positive offshore directed sediment flux gradient between stations $\mathrm{S} 5$ and $\mathrm{S} 4$, and a convergence of sediment flux between S3 and S4 which explains the erosion and accretion, respectively, in these two areas. The transport of sediment was primarily accomplished by mean currents with oscillatory flows being secondary contributors (Table 1). At S4 and S5, offshore directed mean currents on the order of $0.10-0.20 \mathrm{~m} / \mathrm{s}$ (probably undertows) persisted while onshore directed mean flows ranging from $0.05-0.20 \mathrm{~m} / \mathrm{s}$ occurred at $\mathrm{S} 3$. While the presence of the undertow was expected due to the intense wave breaking on the beach and the lack of longshore drainage, the onshore mean flows at S3 are difficult to explain. Visual observations indicated that some wave reforming did occur in the trough between the inner bar and the beach, and as a result, the undertow would have been expected to decrease at S3 but not to reverse to onshore flows. The source of these flows is unknown and further analyses which are beyond the scope of the present paper are required to resolve this question. At any rate, the sediment transport convergence between S3 and S4 initialized a renewed swash bar development.

Storm 3 was more highly energetic than storms 1 and 2 and resulted in a larger loss of sediment (Figure 9). Erosion of the entire width of the intertidal beach and inner surf zone occurred to a depth of $0.1-0.15 \mathrm{~m}$ instead of the more focussed erosion involved in swash bar destruction, and some minor deposition occurred on the incipient swash bar between S3 and S4, again due to a suspended sediment flux convergence between these two stations.

Storm 4 (Nov. 6-7) was by far the most highly energetic event and associated with the largest surge but actually resulted in beach recovery (Figures $7 \mathrm{~b}$ and 9 ). Erosion of the upper beach was minor (while the dune ramp was scarped); significant accretion (up to $0.4 \mathrm{~m}$ ) occurred on the new swash bar and a new rip channel was formed $60 \mathrm{~m}$ 

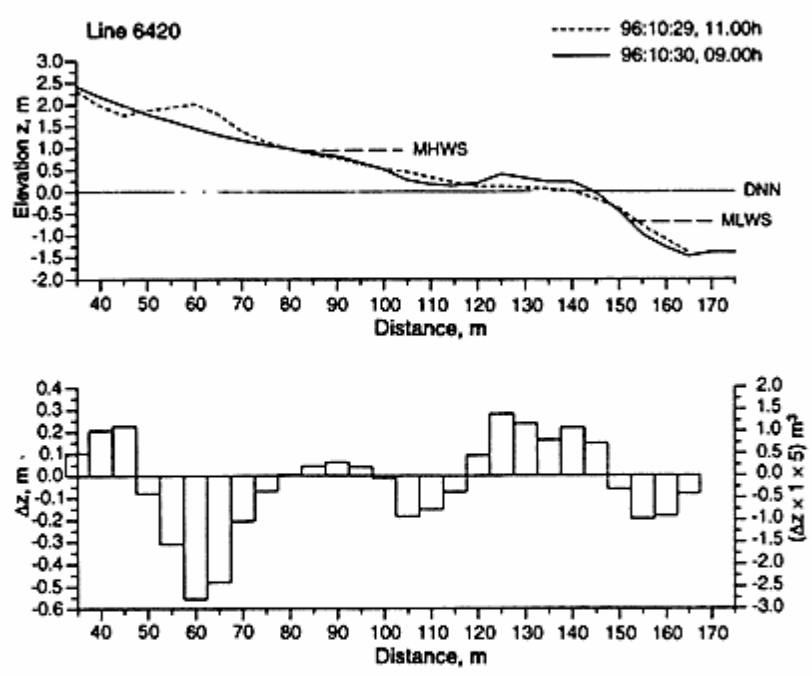

Figure 7a: Cross-shore profile changes during Storm 2, as well as bed elevation changes as recorded at the survey stakes.
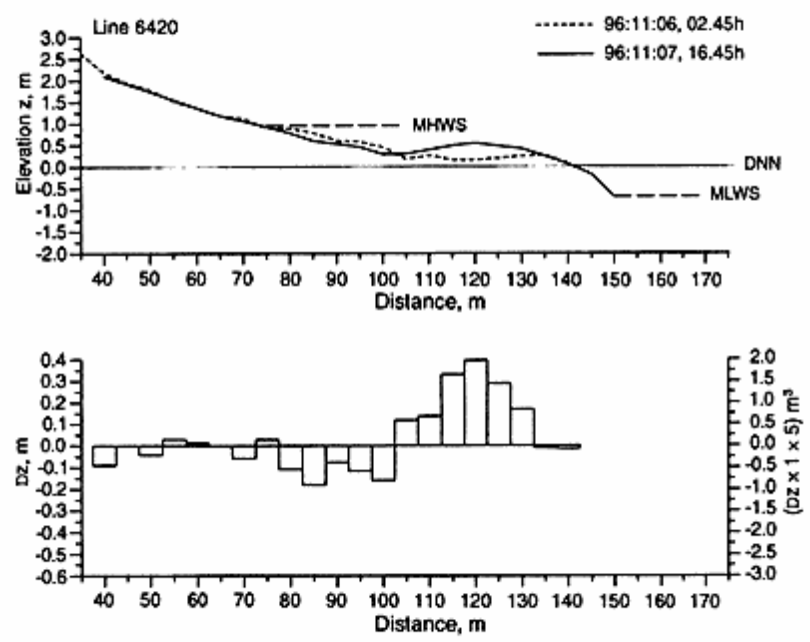

Figure 7b: As Figure 7a, but for Storm 4.

south of the transect. Unfortunately, sediment transport data were not obtained during Storm 4 . This surge was not forecast and access to the field site was impossible for the duration of the event. However, it is highly likely that a renewed cell circulation involving onshore mean currents across the bar and drainage through the rip channel was generated.

The final result was that Storms 1-3 all led to volumetric losses on the beach whereas the largest storm actually led to beach accretion (Figure 9). A similar trend was observed during Hurricane Opal by Davis and Wang (1998). The

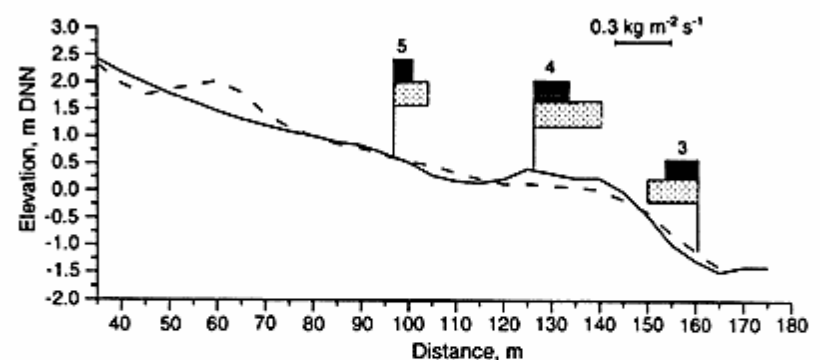

Figure 8: Net suspended sediment transport at stations S3-S5 during run 303_18 (low tide; black signature) and run 304_02 (high tide; cross-hatched). Transports were vertically integrated over the interval $z=0.025-0.25 \mathrm{~m}$. The dashed line is the profile prior to Storm 2 and the solid is the profile after this storm. Run numbers refer to Julian days.

present results illustrate the strong morphodynamic feedback mechanisms existing at Skallingen between the preexisting morphology and the hydrodynamic processes which drive the transport of sediment. As long as a swash bar/runnel complex exists, a cell circulation system is likely to be generated with onshore directed mean flows driving the swash bar onshore. When the runnel fills in, lateral drainage is inhibited and under reasonably energetic conditions an undertow develops, eroding the beach and depositing sediment at the inner edge of the trough between the bar and the beach where undertow velocities decrease. A new swash bar develops at this position, gradually accreting and moving onshore (Figure 6). It is also evident

Table 1: Suspended sediment flux at stations S3-S5 during Storm 2 (runs 303_18 and 304_02). Results are from the lower sensor only and they have been partitioned into transport contributions from mean flows and oscillatory incident and infragravity motions, respectively. Values are given in $\mathrm{kg} \mathrm{m}^{-2} \mathrm{~s}^{-1}$. Positive numbers indicate onshore transport, and visa versa.

\begin{tabular}{lccc}
\hline \multicolumn{4}{c}{ Run 303_18 (low tide) } \\
& mean & oscill. Incident & oscill. Infragravity \\
\hline S5 & -.253 & +.063 & +.085 \\
S4 & -.428 & +-129 & +.112 \\
S3 & +.052 & +.081 & +.027 \\
\hline \multicolumn{3}{c}{ Run 304_02 (high tide) } \\
\hline S5 & -.252 & +.057 & +.010 \\
S4 & -.587 & +.110 & +.092 \\
S3 & +.222 & +.041 & +.005 \\
\hline
\end{tabular}




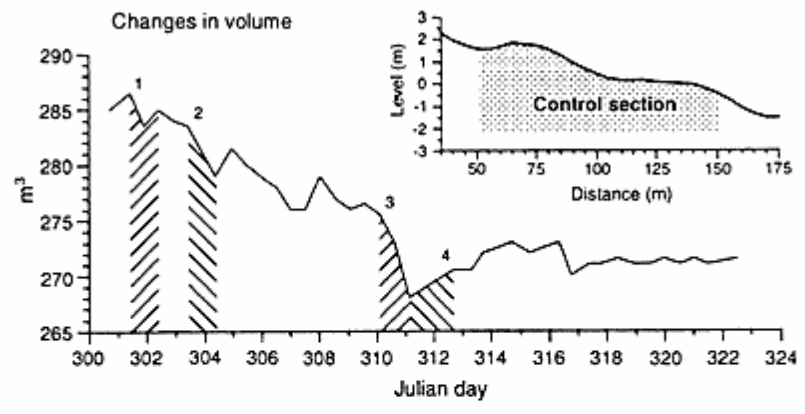

Figure 9: Volumetric change within the control section over the duration of the experiment. The timing of Storms I-4 is indicated. The largest loss was caused by Storm 3.

that as long as a large swash bar is present, erosion of the beach and the dunes will not be significant as the swash bar causes intense wave dissipation and thus protects the upper beach.

\section{Onshore aeolian sediment transport}

Aeolian accretion along the dune transects over the period Nov. 3-8 (Storms 3 and 4) is illustrated in Figure 10. Records for plots 1-5 represent average figures from the equivalent plots along the three separate transects, while plots 0 and -1 only existed along one transect. Accretion was confined mainly to the dune crest but $3-4 \mathrm{~mm}$ of accretion was also observed $45 \mathrm{~m}$ inland. Plots 6-8 which were located on the dune ramp, were removed by wave scarping during Storm 4 . Over the course of these five days, a total of $\sim 0.5 \mathrm{~m}^{3} / \mathrm{m}$ of sand was deposited on and beyond the dune crest.

Figure 10 also illustrates the dune accretion over the year (Nov. 3, 1996-Nov. 18, 1997). Surprisingly large amounts of vertical accretion, in excess of $0.2 \mathrm{~m}$ were recorded. A total of $\sim 9 \mathrm{~m}^{3} / \mathrm{m}$ was deposited over this period. The accretion almost exclusively occurred during the winter season (Nov. 3, 1996-May 6, 1997). The summer season (May 6-Nov. 18, 1997) resulted in an accretion of approximately $0.15 \mathrm{~m}^{3} / \mathrm{m}$ in plots $3-5$. This was balanced, however, by a similar loss in plots $2-\div 1$ which was probably due to sediment compaction. Winter accretion extended well beyond the dune crest with relatively large amounts further landward compared to the five-day autumn period (and the summer season). One reason for
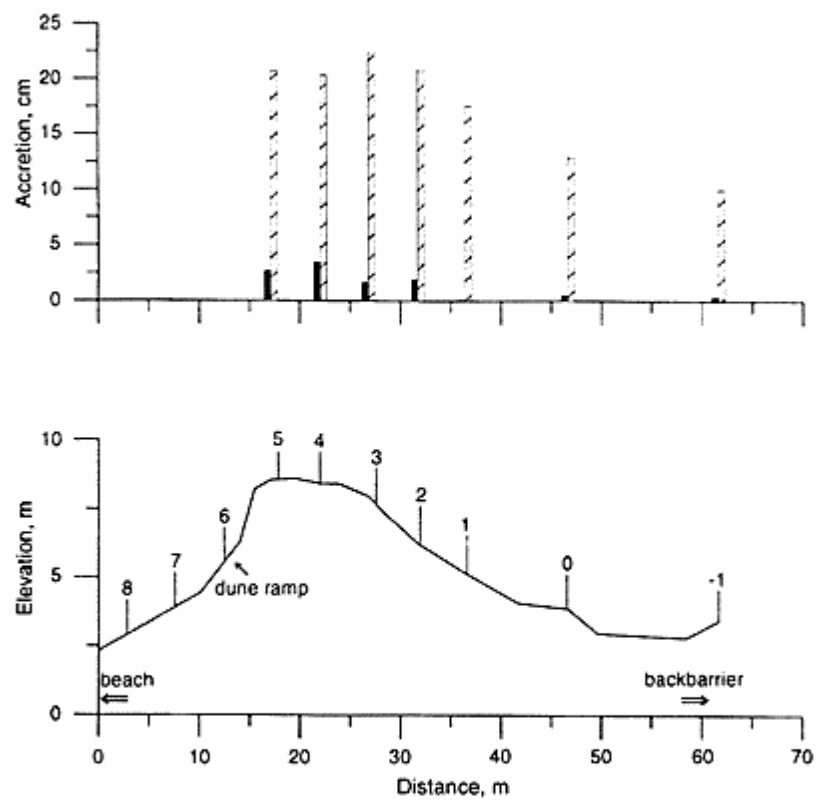

Figure 10: Cross-shore profile of the northern dune transect and aeolian deposition at plots $\div 1-+5$ during the period Nov.3-8 I996 (solid black columns) and November 1996-November 1997 (dotted columns). Results for plots $1-5$ are averages from three transects while plots 0 and $\div 1$ only existed in the northern transect.

the greater horizontal extent of accretion landward may have been that snowcover during the winter reduced the trapping effects of the vegetation.

\section{Longshore sediment transport}

Longshore aeolian and littoral sediment transport was measured simultaneously on Nov. 1 when wind and wave conditions were moderate. Winds were northwesterly and nearly parallel to the beach, blowing $10-12 \mathrm{~m} / \mathrm{s}$. Significant offshore wave heights were approximately $1.0 \mathrm{~m}$ (Figure 3) with longshore current velocities peaking at $0.86 \mathrm{~m} / \mathrm{s}$ over the inner bar crest at low tide, and $0.94 \mathrm{~m} / \mathrm{s}$ over the swash bar crest at high tide. Away from bar crests, longshore current velocities were considerably smaller. The backshore was relatively wide (30-110 m depending on the tidal stage; the dry beach width was 15-40 m) due to moderate water levels with a very long fetch for the aeolian transport due to the shore-parallel wind direction. Conditions were thus favourable to aeolian transport and low $(<0.2 \mathrm{~m})$ transverse dunes progressively developed on the beach during the day. 


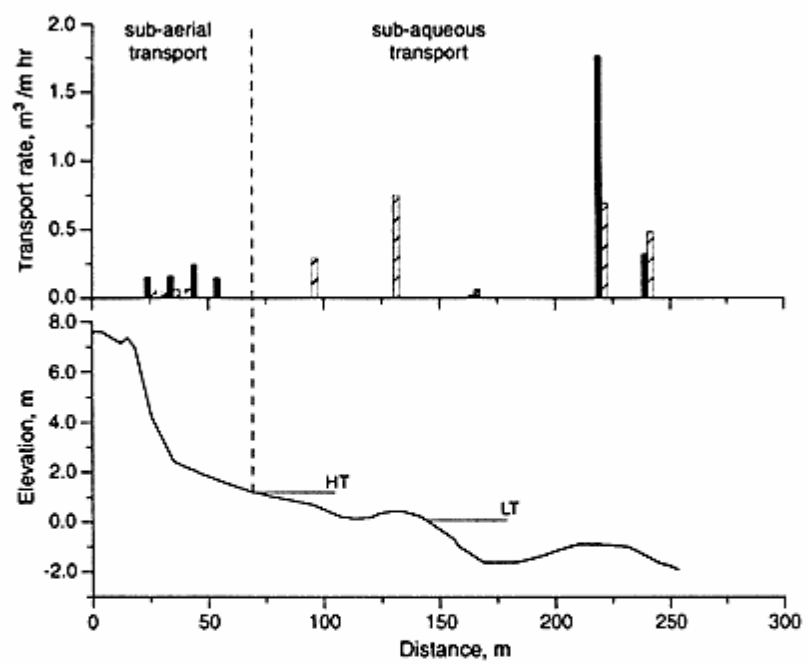

Figure 11: Longshore sediment transport rates due to winds and waves at high tide (cross-hatched columns) and low tide (solid black columns) on Nov.l. High tide (HT) and low tide (LT) limits are indicated.

Aeolian transport estimates were undertaken at low and high tide on Nov. 1. At low tide, a transport peak occurred some distance seaward from the dune ramp (Figure 11) while transport at high tide was restricted due to the narrower (dry) beach and the development of a pebble lag on the upper beach as dry sand was continuously removed. Alongshore aeolian transport rates as estimated from Figure 11 were $\sim 7 \mathrm{~m}^{3} / \mathrm{hr}$ at low tide, decreasing to $\sim 2 \mathrm{~m}^{3} / \mathrm{hr}$ at high tide.

In the surf zone, longshore sediment transport peaks were found at bar crests where peaks in longshore current velocities and sediment concentrations (up to $5.6 \mathrm{~g} / \mathrm{l}$ at $\mathrm{z}=$ $0.05 \mathrm{~m}$ on the inner bar) occurred due to the intense wave breaking/dissipation. In troughs between bars, sediment concentrations were small under the reformed waves (0.4$0.7 \mathrm{~g} / 1$ ), and transport rates were consequently also small. Even though bedload transport, as well as transport in the outer surf zone is unknown, it is obvious from Figure 11 that littoral transport exceeded aeolian transport by about an order of magnitude. At high tide, longshore sediment transport in the inner surf zone amounted to $\sim 80 \mathrm{~m}^{3} / \mathrm{hr}$ while it was $\sim 73 \mathrm{~m}^{3} / \mathrm{hr}$ at low tide thus remaining relatively constant over the recorded tidal cycle. The loss of surf zone width at low tide was offset primarily by larger sediment concentrations over the bar where wave breaking was more intense at low tide. At S2, sediment concen- trations at $\mathrm{z}=0.05 \mathrm{~m}$ increased from $3.0 \mathrm{~g} / \mathrm{l}$ at high tide to $5.6 \mathrm{~g} / \mathrm{l}$ at low tide.

\section{Discussion and conclusions}

The environmental conditions monitored during the present experiment resulted in a number of unexpected morphological consequences. Profile changes on the intertidal beach involved a cyclic behaviour of the swash bar/runnel complex. The swash bar did not erode during storms and accrete during low-energy conditions as would perhaps have been expected (e.g. Hayes and Boothroyd, 1969; Davis et al., 1972). Instead, the swash bar behaviour involved strong positive feedbacks between the morphology and the hydrodynamics. During Storm 1, mean currents and sediment transport were directed onshore over the swash bar probably due to wave- and bore-induced mass transports. These flows formed part of a circulation cell which drained offshore through a shallow rip channel approximately $150 \mathrm{~m}$ south of the instrument transect. The presence of the swash bar resulted in attenuated wave energy levels on the upper beach which did not erode significantly.

During Storm 2, the runnel infilled; lateral drainage was inhibited and an offshore directed undertow was generated which eroded the beach during Storms 2 and 3 while at the same time gradually forming a new swash bar around the mean water level where undertow velocities decreased. Storm 4 which was the most intense resulted in swash bar accretion and renewed onshore migration of this feature, probably associated with a cell circulation as a new rip channel was observed $60 \mathrm{~m}$ south of the transect. Thus, swash bar behaviour and intertidal beach profile evolution at this site is determined mainly by the pre-existing topography whereas wave energy level is of secondary importance.

Another unexpected observation was the fact that the inner nearshore bar migrated landward over the experimental period. Large onshore directed sediment transport rates were recorded over this bar during Storms 2 and 3, while the transport was directed offshore (and smaller) during Storm 1 (Storm 4 was not monitored). Further analyses are required to determine the reason for this unexpected behaviour. Explanations might involve the relatively smaller local wave height/water depth ratios during the significant surges of Storms 2, 3 and 4 and/or the long 
incident wave periods relative to sediment fall velocities (which would promote onshore directed transport in the case of strongly asymmetric waves).

The series of storms experienced at the research site led to a sediment loss of $26.6 \mathrm{~m}^{3} / \mathrm{m}$ from the dunes and the intertidal zone. This loss was very similar to the loss which occurred from the beach at the washover fan north of the research site. At the research site, the sediment was lost from the surveyed profile; accretion further seaward could not be documented and it is likely that a significant fraction of this loss was transported southward toward the tidal inlet at Grådyb. At the washover fan, however, at least $55 \%$ of the sediment loss from the beach was deposited on the surface of the fan, i.e. this sediment remained on the barrier. Assuming that the value determined from this single transect was representative along the $400 \mathrm{~m}$ width of the fan, some $5000 \mathrm{~m}^{3}$ of sand might have been deposited here. These findings corroborate the long-term trends identified by Nielsen (1991) and Aagaard et al. (1995a) which indicate that the formation of washover fans plays a significant role in the preservation of this barrier, similar to earlier findings by e.g. Swift (1975) and Ritchie and Penland (1989).

A further mechanism which can contribute to onshore barrier migration and thus barrier preservation is onshore sediment transport by the wind. Data obtained during this preliminary study indicate that over the fall experimental period, onshore aeolian transport was somewhat smaller than the amount contributed by overwash even though it was distributed over a larger area. Assuming an $8 \mathrm{~km}$ shoreline length of Skallingen, aeolian accretion would have amounted to some $4000 \mathrm{~m}^{3}$. However, on an annual basis, aeolian accretion appears to be much more important than overwash. Over the winter season (when aeolian transport beyond the dunes is much more important than during the calm summer season), some $70000 \mathrm{~m}^{3}$ of sand is inferred to have been deposited along the barrier, again assuming that the long-term figures obtained are representative.

Present estimates (Nielsen, 1991; Aagaard et al., 1995) indicate that the Skallingen shoreline is retreating at an average rate of some $3 \mathrm{~m} /$ year. The average height of the active beach/nearshore profile is on the order of $10 \mathrm{~m}$, corresponding to an average loss of about $2.5 \times 10^{5} \mathrm{~m}^{3}$ of sand from the Skallingen coast, assuming that the crossshore profile shape remains constant. Some of this sediment is preserved on the barrier through aeolian and over- wash processes. The above mentioned preliminary estimates suggest that these mechanisms may transport some $0.8 \times 10^{5} \mathrm{~m}^{3}$ landward. The remainder (some $1.7 \times 10^{5} \mathrm{~m}^{3}$ ) is transported either offshore or alongshore. Future detailed investigations are required to reveal the importance of the former; however, it is probable that a significant fraction of this amount is transported alongshore contributing to the total longshore sediment transport at Skallingen which is estimated to the order of $1 \times 10^{6} \mathrm{~m}^{3} /$ year (DHI, 1992).

Investigations into the relative significance of marine and aeolian mechanisms in the longshore transport at Skallingen, conducted under moderate energy conditions indicate that the former is about an order of magnitude more important than the latter. Total transport (marine and aeolian) comprised some $2000 \mathrm{~m}^{3} / \mathrm{day}$. It is difficult to determine if this figure is representative. Under calm conditions, almost no transport will occur. On the other hand, longshore transport in the subaqueous zone during Storm 2 was about a factor 5 larger than the above estimate while aeolian transport during this storm was insignificant due to very narrow beach widths and wet sand.

In conclusion, a preliminary and very tentative estimate of the sediment budget at the Skallingen coastline suggests that an amount of some $2.5 \times 10^{5} \mathrm{~m}^{3}$ of sand is annually eroded from the dunes/beach/nearshore. Approximately $30-35 \%$ of this amount may be retained on the barrier through aeolian transport and overwash while the remainder is transported southward (and/or offshore). The amount transported alongshore enters the Grådyb tidal inlet; under natural conditions a large fraction of this volume would be introduced into the lagoon through flood delta deposits (e.g. Davis, 1994); at present, this sediment is dredged from the inlet.

\section{Acknowledgements}

Our sincere appreciation goes to Ulf Thomas, who did an outstanding job in getting our instruments up and running and who was always on call to solve problems with unwanted electronic noise. Rune Butzbach, Christian Helledie, Kalle Kronholm, Rasmus Nielsen and Carlo Sørensen (U. of Copenhagen), and Carl Boldy and Kitty Brown (U. of Toronto) assisted in the field. The Esbjerg Harbour Authorities supplied data on winds and tides. The study was funded by the Danish Natural Sciences Research Council, grant no. 11-0925. 


\section{References}

Aagaard, T. \& Greenwood, B. (1995): Suspended sediment transport and morphological response on a dissipative beach. Continental Shelf Research, 15, 1061-1086.

Aagaard, T., Nielsen, J., Greenwood, B., Christiansen, C., LundHansen, L.C. \& Nielsen, N. (1995b): Coastal morphodynamics at Skallingen. SW Denmark: Low and moderate energy conditions. Danish Journal of Geography, 95, 1-11.

Aagaard, T., Nielsen, J. \& Greenwood, B. (in press): Suspended sediment transport and near-shore bar formation on a shallow intermediate beach. Marine Geology, in press.

Aagaard, T., Nielsen, J., Nielsen, N. \& Greenwood, B. (1998): Suspended sediment transport and morphological evolution on an intertidal beach. Proceedings Coastal Dynamics 1997. ASCE, in press.

Aagaard, T., Nielsen, N. \& Nielsen, J. (1995a): Skallingen Origin and Evolution of a Barrier Spit. Medd.f. Skallinglab., XXXV, 85pp.

Bird, E.C.F. (1993): Submerging Coasts. Wiley and Sons, Chichester, 184pp.

Birkemeier, W.A., Bichner, E.W., Scarborough, B.L., McConathy, M.A. \& Eiser, W.C. (1991): Nearshore profile response caused by Hurricane Hugo. Journal of Coastal Research SI8, 113-128.

Carter, R.W.G. (1988): Coastal Environments. Academic Press, London, 617pp.

Davidson-Arnott, R.G.D. \& Law, M.N. (1990): Seasonal patterns and controls on sediment supply to coastal foredunes, Long Point, Lake Erie. In: K.F.Nordstrom, N.Psuty and R.W.G. Carter (ed) Coastal Dunes, Wiley Science, 177-200.

Davidson-Arnott, R.G.D. \& Law, M.N. (1996): Measurement and prediction of long-term sediment supply to coastal foredunes. Journal of Coastal Research, 12, 654-663.

Davidson-Arnott, R.G.D., Nielsen, J., Aagaard, T. \& Greenwood, B. (1997): Alongshore and onshore aeolian sediment transport, Skallingen, Denmark. Proceedings Canadian Coastal Conference, 1997, NSERC, 463-476.

Davis, R.A. (1994): Barrier island systems - a geologic overview. In: R.A.Davis (ed) Geology of Holocene Barrier Island Systems, Springer Verlag, 1-46.

Davis, R.A., Fox, W.T., Hayes, M.O. \& Boothroyd, J.C. (1972): Comparison of ridge and runnel systems in tidal and non-tidal environments. Journal of Sedimentary Petrology, 42, 413-421.

Davis, R.A. \& Wang, P. (1998): Hurricane Opal induced changes on natural and nourished beaches, west-central Florida. Proceedings 25th Coastal Engineering Conferencpe, ASCE, 29822993.

DHI (1992): Matematisk simulering af sedimentation og bølgeudbredelse i Grådybområdet. Littoraltransport langs Skallingen. Upubl.rapport, Kyst-Havnesamarbejdet,

Dingler, J.R. \& Reiss, T.E. ( 1990$)$ : Cold-front driven storm erosion and overwash in the central part of the Isles Dernieres, a Louisiana barrier island arc. Marine Geology, 91, 195-206.

Hayes, M.O. \& Boothroyd, J.C. (1969): Storms as modifying agents in the coastal environment. SEPM Field Guide, Coastal Environments NE Massachusetts and New Hampshire.

Hazen, D.G., Doering, J.C. \& Bowen, A.J. (1989): A note on a low-cost pressure sensor for nearshore wave measurement. Continental Shelf Research, 14, 85-90.

Kahn, J.H. \& Roberts, H.H. (1982): Variations in storm response along a microtidal transgressive barrier island arc. Sedimentary Geology, 33, 129-146

Komar, P.D. (1976): Beach Processes and Sedimentation. Prentice-Hall, Englewood Cliffs, 476pp.

Nickling, W.G. \& McKenna Neuman, C. (1997): Wind tunnel evaluation of a wedge-shaped aeolian sediment trap. Geomorphology, 18, 333-345.

Nielsen, $N$. (199I): Skallingen - dannelse og udvikling. Delrapport 1: En Geomorfologisk analyse af Skallingen. Upubl. rapport Kyst-Havnesamarbejdet, 48s.

Ritchie, W. \& Penland, S. (1988): Rapid dune changes associated with overwash processes on the deltaic coast of South Louisiana. Marine Geology, 81, 97-122.

Ritchie, W. \& Penland, S. (1989): Erosion and washover in coastal Louisiana. In: D.K.Stauble (ed) Barrier Islands: Process and Management. ASCE, 253-264.

Sallenger, A.H., Holman, R.A. \& Birkemeier, W.A. (1985): Storm-induced response of a near-shore-bar system. Marine Geology, 64, 237-257.

Swift, D.J.P. (1975): Barrier island genesis: evidence from the central Atlantic shelf, Eastern U.S.A. Sedimentary Geology, 14, 1-43.

Viles, H. \& Spencer, T. (1995): Coastal Problems. Geomorphology, Ecology and Society at the Coast. Edward Amold, London, 350pp.

Wright, L.D. \& Short, A.D. (1984): Morphodynamic variability of surf zones and beaches: a synthesis. Marine Geology. 56, 93-118. 
incident wave periods relative to sediment fall velocities (which would promote onshore directed transport in the case of strongly asymmetric waves).

The series of storms experienced at the research site led to a sediment loss of $26.6 \mathrm{~m}^{3} / \mathrm{m}$ from the dunes and the intertidal zone. This loss was very similar to the loss which occurred from the beach at the washover fan north of the research site. At the research site, the sediment was lost from the surveyed profile; accretion further seaward could not be documented and it is likely that a significant fraction of this loss was transported southward toward the tidal inlet at Grådyb. At the washover fan, however, at least $55 \%$ of the sediment loss from the beach was deposited on the surface of the fan, i.e. this sediment remained on the barrier. Assuming that the value determined from this single transect was representative along the $400 \mathrm{~m}$ width of the fan, some $5000 \mathrm{~m}^{3}$ of sand might have been deposited here. These findings corroborate the long-term trends identified by Nielsen (1991) and Aagaard et al. (1995a) which indicate that the formation of washover fans plays a significant role in the preservation of this barrier, similar to earlier findings by e.g. Swift (1975) and Ritchie and Penland (1989).

A further mechanism which can contribute to onshore barrier migration and thus barrier preservation is onshore sediment transport by the wind. Data obtained during this preliminary study indicate that over the fall experimental period, onshore aeolian transport was somewhat smaller than the amount contributed by overwash even though it was distributed over a larger area. Assuming an $8 \mathrm{~km}$ shoreline length of Skallingen, aeolian accretion would have amounted to some $4000 \mathrm{~m}^{3}$. However, on an annual basis, aeolian accretion appears to be much more important than overwash. Over the winter season (when aeolian transport beyond the dunes is much more important than during the calm summer season), some $70000 \mathrm{~m}^{3}$ of sand is inferred to have been deposited along the barrier, again assuming that the long-term figures obtained are representative.

Present estimates (Nielsen, 1991; Aagaard et al., 1995) indicate that the Skallingen shoreline is retreating at an average rate of some $3 \mathrm{~m} /$ year. The average height of the active beach/nearshore profile is on the order of $10 \mathrm{~m}$, corresponding to an average loss of about $2.5 \times 10^{5} \mathrm{~m}^{3}$ of sand from the Skallingen coast, assuming that the crossshore profile shape remains constant. Some of this sediment is preserved on the barrier through aeolian and over- wash processes. The above mentioned preliminary estimates suggest that these mechanisms may transport some $0.8 \times 10^{5} \mathrm{~m}^{3}$ landward. The remainder (some $1.7 \times 10^{5} \mathrm{~m}^{3}$ ) is transported either offshore or alongshore. Future detailed investigations are required to reveal the importance of the former; however, it is probable that a significant fraction of this amount is transported alongshore contributing to the total longshore sediment transport at Skallingen which is estimated to the order of $1 \times 10^{6} \mathrm{~m}^{3} /$ year (DHI, 1992).

Investigations into the relative significance of marine and aeolian mechanisms in the longshore transport at Skallingen, conducted under moderate energy conditions indicate that the former is about an order of magnitude more important than the latter. Total transport (marine and aeolian) comprised some $2000 \mathrm{~m}^{3} / \mathrm{day}$. It is difficult to determine if this figure is representative. Under calm conditions, almost no transport will occur. On the other hand, longshore transport in the subaqueous zone during Storm 2 was about a factor 5 larger than the above estimate while aeolian transport during this storm was insignificant due to very narrow beach widths and wet sand.

In conclusion, a preliminary and very tentative estimate of the sediment budget at the Skallingen coastline suggests that an amount of some $2.5 \times 10^{5} \mathrm{~m}^{3}$ of sand is annually eroded from the dunes/beach/nearshore. Approximately $30-35 \%$ of this amount may be retained on the barrier through aeolian transport and overwash while the remainder is transported southward (and/or offshore). The amount transported alongshore enters the Grådyb tidal inlet; under natural conditions a large fraction of this volume would be introduced into the lagoon through flood delta deposits (e.g. Davis, 1994); at present, this sediment is dredged from the inlet.

\section{Acknowledgements}

Our sincere appreciation goes to Ulf Thomas, who did an outstanding job in getting our instruments up and running and who was always on call to solve problems with unwanted electronic noise. Rune Butzbach, Christian Helledie, Kalle Kronholm, Rasmus Nielsen and Carlo Sørensen (U. of Copenhagen), and Carl Boldy and Kitty Brown (U. of Toronto) assisted in the field. The Esbjerg Harbour Authorities supplied data on winds and tides. The study was funded by the Danish Natural Sciences Research Council, grant no. 11-0925. 